\title{
Short communication: Influence of shortening the dry period of Swedish dairy cows on plasmin activity in milk
}

\author{
Ruben de Vries, ${ }^{*} \dagger^{1}$ Melanie Brandt, $\ddagger$ Åse Lundh, $\ddagger$ Kjell Holtenius, ${ }^{*}$ Kasper Hettinga, $\dagger$ \\ and Monika Johanssonł \\ *Department of Animal Nutrition and Management, Swedish University of Agricultural Sciences, PO Box 7024,750 07 Uppsala, Sweden \\ †Dairy Science and Technology, Food Quality and Design, Wageningen University, PO Box 8129, 6700 EV, Wageningen, the Netherlands \\ łDepartment of Food Science, Swedish University of Agricultural Sciences, PO Box 7051, 75007 Uppsala, Sweden
}

\begin{abstract}
The aim of this study was to evaluate the influence of shortening the dry period of Swedish dairy cows on plasmin activity and casein composition in milk. Swedish Holstein and Swedish Red cows, 45 in total, were assigned to a dry period of either 4 or 8 wk. Milk samples were taken 10 and 5 wk prepartum, and 6 and 12 wk postpartum. Plasmin activity and plasminogen activity were measured with a spectrophotometric assay. Casein composition was measured by capillary zone electrophoresis. Prepartum plasminogen activity increased by $22 \%$ between 10 and 5 wk prepartum, whereas no change in plasmin activity was observed during the same period. Cows with a 4 -wk dry period had $61 \%$ higher plasmin activity in postpartum milk than cows with an 8-wk dry period. Cows of third or greater parity tended to have a stronger increase in plasmin activity as a result of applying a short dry period than cows of second parity. Although the $\alpha_{\mathrm{S1}^{-}}$and $\beta$-casein fractions declined with increasing plasmin activity, no dry period effects were found. Based on postpartum differences in plasmin activity, it was concluded that particularly multiparous cows require more than $4 \mathrm{wk}$ between lactations for recovery of the mammary epithelium. Changes in casein composition as an effect of plasmin activity are not expected to have a great effect on processing quality of milk, although future work is needed to verify this.
\end{abstract}

Key words: dairy cow, dry period, milk quality, plasmin activity, casein composition

\section{Short Communication}

A conventional dry period of 6 to 8 wk before parturition is known to maximize milk yield of dairy cows in their successive lactation (Kuhn et al., 2005; Watters

Received May 24, 2016.

Accepted July 16, 2016.

${ }^{1}$ Corresponding author: ruben2.devries@wur.nl et al., 2008; van Knegsel et al., 2014). High peak milk production of cows subjected to a conventional dry period may result in a deep negative energy balance in early lactation, which is related to increased risk of metabolic problems (Rastani et al., 2005; van Knegsel et al., 2013) and reduced fertility (Butler, 2003; Gumen et al., 2005). Shortening the dry period is a way to improve the energy balance in early lactation (Rastani et al., 2005; van Knegsel et al., 2014).

When a shorter $(28-35 \mathrm{~d})$ instead of a conventional 56- to 64-d dry period was applied, postpartum milk yield was reported to be $1.4 \mathrm{~kg} / \mathrm{d}$ lower. Protein percentage was $0.06 \%$ higher in milk of cows with a short dry period compared with a conventional dry period, whereas milk fat percentage was not affected by shortening the dry period (van Knegsel et al., 2013). The postpartum $\alpha_{S 1}$-casein fraction was $3.8 \%$ lower in milk of cows with a 30-d dry period compared with a 60-d dry period, whereas the $\alpha_{S_{2}}-\mathrm{CN}$ fraction was $5.5 \%$ lower when a 30-d dry period was applied (de Vries et al., 2015). Omitting the dry period resulted in a reduced $\beta-\mathrm{CN}$ fraction, which was suggested to be a result of increased proteolytic activity (de Vries et al., 2015). These recent findings have provided an overview of compositional changes of milk as a result of shortening the dry period of the cow. The cause of compositional changes is, however, not well understood.

Plasmin is the main endogenous protease in bovine milk. It is converted from its inactive zymogen plasminogen by the action of plasminogen activators. Plasmin and plasminogen originate from blood and are transported passively to milk through tight junctions in the mammary epithelium (Kelly and McSweeney, 2003). In the mammary gland, plasmin facilitates tissue remodeling by protein degradation and activation of other enzymes (Politis, 1996). The function of plasmin in milk is not clear yet. Plasmin activity in milk was shown to increase with advancing stage of lactation (Politis et al., 1989a; Bastian et al., 1991), fourth or greater parity (Politis et al., 1989a; Bastian et al., 1991), and SCC in milk higher than 300,000 cells/mL (Politis et 
al., 1989a). Plasmin can hydrolyze $\alpha_{\mathrm{S}^{-}} \mathrm{CN}, \alpha_{\mathrm{S} 2}-\mathrm{CN}$, and $\beta-\mathrm{CN}$ in milk. Reduced casein fractions in milk may lead to defects in processing such as reduced cheese yield and curd firmness (Mara et al., 1998; Srinivasan and Lucey, 2002). However, no relation was found between naturally present plasmin activity and clotting parameters of milk (Bastian et al., 1991). Plasmin is a relatively heat stable enzyme (Prado et al., 2007) that may affect protein stability during storage of UHT milk (Rauh et al., 2014) or milk protein ingredients (Gazi et al., 2014).

The aim of this study was to evaluate the influence of shortening the dry period of dairy cows on plasmin and plasminogen activity, and the consequence of plasmin activity for casein composition.

Forty-five clinically healthy cows with proper udder health of the Swedish Holstein $(\mathbf{S H}, \mathrm{n}=21)$ or Swedish Red $(\mathbf{S R}, \mathrm{n}=24)$ breed were included in this study. A dry period of $4 \mathrm{wk}(\mathrm{n}=26$, of which $13 \mathrm{SH}, 13 \mathrm{SR})$ or 8 wk (n $=19$, of which $8 \mathrm{SH}, 11 \mathrm{SR})$ was applied to the cows. The dry period groups consisted of both primiparous and multiparous cows ( 4 wk dry, primiparous $\mathrm{n}=$ 15 , multiparous $\mathrm{n}=11 ; 8$ wk dry primiparous $\mathrm{n}=13$, multiparous $\mathrm{n}=6$ ). Cows were randomly assigned to either a 4-wk or an 8-wk dry period. Cows that, $1 \mathrm{wk}$ before the experiment, yielded less than $15 \mathrm{~kg}$ of milk/d or had signs of reduced udder health were excluded from the study $(\mathrm{n}=3)$. The cows were housed at the Swedish Livestock Research Centre, Lövsta, in an indoor loose house system with slatted floor and cubicles with rubber mats and chopped straw as bedding. Lactating cows were batch-milked twice daily at 0600 and $1600 \mathrm{~h}$ in an automatic milking rotary (DeLaval AMR, Tumba, Sweden). Before drying off, the cows were fed silage ad libitum and concentrate according to milk production. The week before drying off, concentrate was withdrawn and during the dry-off procedure the cows were fed $4 \mathrm{~kg}$ DM of silage and straw ad libitum and no concentrate. No intramammary antibiotics were used at drying off. During the dry period, cows were fed a blend of silage and straw ad libitum and concentrate was stepwise increased to $3 \mathrm{~kg}$ at parturition. After calving, silage was provided ad libitum while the supply of concentrate was increased stepwise to $13.5 \mathrm{~kg} / \mathrm{d}$. Water was always available ad libitum.

Milk samples from the morning milking were taken 10 and 5 wk prepartum, and 6 and 12 wk postpartum. Bronopol $(0.3 \%)$ was added as a preservative to milk samples. Milk samples were stored at $-20^{\circ} \mathrm{C}$ directly after collection. Milk yields were automatically recorded in the robot, whereas milk fat and protein percentage and SCC were analyzed at the Department of Animal Nutrition and Management, SLU Uppsala, using Fourier transform infrared spectroscopy and flow cytometry with fluorescence cell staining (Foss Electric, Hillerød, Denmark). Prepartum plasmin and plasminogen activity were only analyzed in milk of cows with a 4-wk dry period, allowing the comparison of wk 5 and 10 prepartum. No prepartum comparison between dry period groups was made for plasmin and plasminogen activity. The Uppsala Local Ethics Committee approved the experimental protocol $(\mathrm{C} 178 / 12)$.

Milk samples were analyzed for both plasmin activity and plasminogen activity by a method modified from Korycha-Dahl et al. (1983). Chemicals were obtained from Sigma-Aldrich (Sigma-Aldrich Inc., Stockholm, Sweden), except where stated differently. The reaction mixture in which plasmin and plasminogen activity were measured consisted of $0.5 \mathrm{~mL}$ of milk and $7.5 \mathrm{~mL}$ of plasmin buffer (50 $\mathrm{m} M$ Trizma-HCl pH 7.4, $117 \mathrm{mM}$ $\mathrm{NaCl}, 25 \mathrm{~m} M$ ह-amino-n-caproic acid, pH 7.4). After $1 \mathrm{~h}$ incubation at room temperature, the milk serum containing the plasmin and plasminogen was separated from casein micelles by ultracentrifugation (LKB Ultrospin, Sweden) with an RP55T angle rotor, $12 \mathrm{~mL} \times$ 12 at $100,000 \times g$ for $1 \mathrm{~h}$ at $4^{\circ} \mathrm{C}$. Plasmin activity was measured in the serum with the pyro-GLU-Phe-Lys$p$-nitroanilide hydroxychloride chromogenic substrate [2.5 mg/mL; Biophen CS-41(03), Aniara, Westchester, $\mathrm{OH}]$ in a Sarstedt 96-well plate (Sarstedt, Helsingborg, Sweden). Plasminogen activity was determined after addition of urokinase (49.5 plough units) for activation of plasminogen into plasmin. Plasmin and total activity (i.e., combined plasmin and plasminogen activity) were measured continuously every third minute for $120 \mathrm{~min}$ by a multi-mode microplate reader (FLUOstar Omega, BMG Labtech, Ortenberg, Germany) at $37^{\circ} \mathrm{C}$. The change in absorbance $(\Delta \mathrm{A} 405 / \Delta \mathrm{t})$ was used for the measurement of plasmin activity, where the formation of $p$-nitroanilide was calculated from the linear part of the absorbance versus time curve. Plasminogen activity was calculated as the difference between the total activity and plasmin activity. Plasmin and plasminogen activities were expressed in the same units, with 1 unit being defined as the amount of enzyme that produces a $\Delta \mathrm{A} 405$ of 0.001 per minute at $\mathrm{pH} 7.4$ and $37^{\circ} \mathrm{C}$ due to $p$-nitroanilide released from CS-41(03) substrate in the defined reaction mixture. The intra-assay coefficient of variation was $5 \%$ for both plasmin and plasminogen activity, with a maximum CV of $10 \%$ per 96 -well plate.

Casein composition of milk samples was determined by capillary zone electrophoresis as described by de Vries et al. (2015).

A mixed model accounting for repeated measures (SAS 9.3, SAS Institute Inc., Cary, NC) was used for comparison between treatments, in which cows were the repeated subject. Prepartum and postpartum results were analyzed separately. The $P$-values were corrected 
Table 1. Means for milk yield and composition of cows with a 4-wk dry period

\begin{tabular}{|c|c|c|c|c|}
\hline \multirow[b]{2}{*}{ Item } & \multicolumn{2}{|c|}{ Week relative to calving } & \multirow[b]{2}{*}{ SEM } & \multirow{2}{*}{$\frac{P \text {-value }}{\text { Week }^{1}}$} \\
\hline & -10 & -5 & & \\
\hline Milk yield (kg/d) & 24.4 & 19.5 & 1.7 & $<0.01$ \\
\hline Fat $(\%)$ & 4.82 & 4.76 & 0.20 & 0.36 \\
\hline Protein $(\%)$ & 3.91 & 4.10 & 0.12 & 0.06 \\
\hline $\mathrm{SCC}^{2}\left(\times 10^{3}\right.$ cells $\left./ \mathrm{mL}\right)$ & 94 & 100 & 28 & 0.15 \\
\hline Plasmin activity (units/mL) & 7.3 & 8.0 & 1.9 & 0.14 \\
\hline Plasminogen activity (units $/ \mathrm{mL}$ ) & 74.3 & 90.9 & 6.7 & $<0.01$ \\
\hline$\alpha_{\mathrm{S}_{1}-\mathrm{CN}}(\%$ of total protein) & 28.4 & 28.2 & 0.8 & 0.35 \\
\hline$\alpha_{\mathrm{S}_{2}} \mathrm{CN}$ (\% of total protein) & 7.8 & 8.3 & 0.5 & 0.04 \\
\hline$\beta-\mathrm{CN}(\%$ of total protein) & 34.0 & 34.0 & 1.2 & 0.60 \\
\hline$\kappa-\mathrm{CN}$ ( $\%$ of total protein) & 10.1 & 9.6 & 0.5 & 0.57 \\
\hline$\alpha$-LA ( $\%$ of total protein) & 3.0 & 2.9 & 0.1 & 0.64 \\
\hline$\beta-\mathrm{LG}$ ( $\%$ of total protein) & 10.7 & 10.7 & 0.4 & 0.86 \\
\hline
\end{tabular}

${ }^{1} P$-values for week are based on milk samples of cows with a 4 -wk dry period $(\mathrm{n}=25)$ at 5 or 10 wk prepartum. Also included in the model are the interactions week $\times$ breed, week $\times$ parity, and breed $\times$ parity.

${ }^{2}$ Statistical analysis based on log-values.

by Bonferroni adjustment. Differences were considered to be significant if $P<0.05$.

Prepartum comparison between dry period lengths was done with samples of wk -10 . Fixed factors in the mixed model were dry period (4 or 8 wk), breed (SH or SR), and parity (first, second, or greater). The interactions dry period $\times$ breed, dry period $\times$ parity, and breed $\times$ parity were also included in the model. Prepartum comparison between sampling weeks was done with milk samples from cows in the 4-wk dry period group. Fixed factors in the model were sampling week $(-10$ or $-5 \mathrm{wk}$ ), breed (SH or SR), and parity (first, second, or greater). The interactions sampling week $\times$ breed, sampling week $\times$ parity, and breed $\times$ parity were also included in the model.

One model was used for postpartum samples, including the fixed factors dry period (4 or 8 wk), sampling week (6 or $12 \mathrm{wk}$ ), breed (SH or SR), and parity (second, third, or greater). The interactions dry period $x$ sampling week, dry period $\times$ breed, dry period $\times$ parity, sampling week $\times$ breed, sampling week $\times$ parity, and breed $\times$ parity were also included in the postpartum model. An autoregressive covariance structure had the best fit for all variables, both pre- and postpartum, and was used to account for within-cow variation.

Cows in the 4-wk dry period group had a higher milk yield $(24.4 \mathrm{~kg} / \mathrm{d})$ than cows in the 8 -wk dry period group $(19.9 \mathrm{~kg} / \mathrm{d})$ at $10 \mathrm{wk}$ prepartum $(P<0.01)$. Swedish Reds had lower milk yield $(18.5 \mathrm{~kg} / \mathrm{d})$ than $\mathrm{SH}(24.3$ $\mathrm{kg} / \mathrm{d})$ at $10 \mathrm{wk}$ prepartum $(P<0.01)$. Milk yield was significantly influenced by the interaction of dry period $\times$ breed $(P=0.04)$. Swedish Holsteins with a 4 -wk dry period $(28.2 \mathrm{~kg} / \mathrm{d})$ had higher milk yield than $\mathrm{SH}$ with an 8-wk dry period $(20.4 \mathrm{~kg} / \mathrm{d})$, whereas SR with a 4 or 8-wk dry period had similar milk yield. Milk yield of cows with a 4 -wk dry period was higher $(P<0.01)$ at
10 wk prepartum $(24.4 \mathrm{~kg} / \mathrm{d})$ than at 5 wk prepartum $(19.5 \mathrm{~kg} / \mathrm{d}$; Table 1). Postpartum milk yield of cows that had an 8 -wk dry period $(42.9 \mathrm{~kg} / \mathrm{d})$ was higher compared with cows that had a 4-wk dry period (38.2 $\mathrm{kg} / \mathrm{d}$; Table 2), which is was larger than was reported before $(-1.5 \mathrm{~kg} / \mathrm{d}$ ) in a meta-analysis (van Knegsel et al., 2013). The unexpected prepartum difference seems not to have influenced postpartum results, but rather lead to underestimation of the effect size. Postpartum milk yield was higher at $6 \mathrm{wk}(41.6 \mathrm{~kg} / \mathrm{d})$ than at $12 \mathrm{wk}$ of lactation $(38.6 \mathrm{~kg} / \mathrm{d})$ (Table 2$)$.

Milk macronutrient composition prepartum did not differ between cows with a 4- or 8-wk dry period, and neither did milk protein composition. Swedish Holsteins had lower milk protein percentage $(3.93 \%)$ than SR $(4.12 \%)$ at 10 wk prepartum $(P=0.04)$. Milk protein percentage was particularly lower for $\mathrm{SH}$ with a 4 -wk dry period $(3.73 \%)$, compared with SH with an 8-wk dry period $(4.14 \%)$ or SR $(P<0.01)$. At 10 wk prepartum, 3 milk samples had SCC between 250,000 and 500,000 cells $/ \mathrm{mL}$. None of the prepartum milk samples had SCC $>500,000$ cells $/ \mathrm{mL}$. Plasminogen activity was higher $(P<0.01)$ at 5 wk prepartum $(90.9$ units $/ \mathrm{mL})$ than at 10 wk prepartum (74.3 units $/ \mathrm{mL})$. Such an increase in plasminogen activity with advancing lactation has been reported before (Bastian et al., 1991; Nicholas et al., 2002). Plasminogen activity correlated negatively with milk yield $\left(\mathrm{R}^{2}=0.20, P<0.01\right)$ and positively with milk protein percentage $\left(\mathrm{R}^{2}=0.45, P<\right.$ 0.01 ), whereas plasmin activity did not. These results indicate a concentration effect of plasminogen during late lactation due to the correlations with milk yield, as was reported before (Schaar and Funke, 1986). Plasmin activity did not differ between milk samples taken either 5 or $10 \mathrm{wk}$ prepartum, which is in accordance with Dupont et al. (1998). Other work, however, in- 
dicated an increase in plasminogen activation toward the end of lactation (Politis et al., 1989b), which was not confirmed by the current results. Primiparous cows had lower plasmin activity in milk at either 5 or 10 wk prepartum (5.6 units $/ \mathrm{mL}$ ) than multiparous cows (11.9 units $/ \mathrm{mL}$ ). Proteolytic activity toward caseins did not seem to increase between 10 and 5 wk prepartum, because none of the casein fractions reduced between 10 and 5 wk prepartum. The $\alpha_{\mathrm{S}^{-}} \mathrm{CN}$ fraction was higher $(P=0.04)$ at 5 wk prepartum $(8.3 \%)$ than at 10 wk prepartum (7.8\%). Milk of $\mathrm{SH}$ had a lower $\alpha$-LA fraction $(2.7 \%)$ than milk of SR (3.1\%) at $10 \mathrm{wk}$ prepartum. Negative correlations were found between plasmin activity and $\alpha_{\mathrm{S}^{-}}$and $\beta-\mathrm{CN}$ fractions, but these were strongly determined by 1 milk sample with high plasmin activity. All in all, the current work shows that milking cows until 4 wk prepartum does not result in increased plasmin activity or casein breakdown in late lactation milk.

In samples taken either 6 or 12 wk postpartum, milk fat percentage of SR (3.96\%) was higher than of $\mathrm{SH}$ $(3.55 \%)$. Milk protein percentage was higher at $12 \mathrm{wk}$ $(3.39 \%)$ than at 6 wk postpartum $(3.33 \%)$. Cows with an 8-wk dry period had a lower milk protein percentage at 6 wk postpartum $(3.21 \%)$ than at 12 wk postpartum, whereas cows with a 4 -wk dry period had similar protein percentage at either 6 or 12 wk postpartum. This resulted in a significant dry period $\times$ week interaction $(P=0.03)$. The SCC was higher in milk of SR $(393,000$ cells/mL) than SH $(208,000$ cells/mL). Swedish Holsteins with an 8-wk dry period had lower SCC $(51,000$ cells/mL) than SH with a 4-wk dry period $(270,000$ cells $/ \mathrm{mL}$ ), or SR with any dry period, resulting in a dry period $\times$ breed interaction $(P=0.03)$. In total, 14 cows had SCC in milk $>250,000$ cells $/ \mathrm{mL}$ at $6 \mathrm{wk}$ postpartum $(\mathrm{n}=3), 12$ wk postpartum $(\mathrm{n}=6)$, or both $(\mathrm{n}=5)$. The $\alpha_{\mathrm{S}^{-}} \mathrm{CN}$ fraction was higher at $6 \mathrm{wk}$ postpartum $(8.8 \%)$ than at 12 wk postpartum $(8.1 \%$; $P<0.01)$. The $\alpha$-LA fraction was higher in the 6 th $(3.7 \%)$ than in the 12 th $(3.5 \%)$ week postpartum $(P<$ $0.01)$. Cows of parity greater than second had higher $\alpha$-LA fraction at 6 wk $(3.9 \%)$ than at 12 wk postpartum $(3.3 \%)$, whereas no difference between weeks was observed for cows of second parity, which resulted in a parity $\times$ week interaction $(P<0.01)$. Like prepartum, the $\alpha$-LA fraction was higher in milk of SR (3.8\%) than SH $(3.4 \% ; P=0.04)$.

In previous work, it was suggested that complete omission of the dry period resulted in higher proteolytic activity in milk based on lower $\beta-\mathrm{CN}$ fractions. Applying a 30-d dry period did not affect the $\beta-\mathrm{CN}$ fraction in the same study (de Vries et al., 2015). The plasmin activity assay used in the current study gives a more sensitive measure for plasmin activity than the $\beta-\mathrm{CN}$ fraction that was used previously to indicate proteolytic breakdown. The current results show that plasmin activity in milk samples 6 or 12 wk postpartum was higher of cows with a 4 -wk dry period (5.0 units/ $\mathrm{mL}$ ) than of cows with an 8-wk dry period (3.1 units/ $\mathrm{mL} ; P<0.01$, Table 2). Cows of third or greater parity had higher plasmin activity $(5.8$ units $/ \mathrm{mL})$ than cows of second parity (3.5 units/mL, $P=0.02$ ). Dry period length and parity tended to interact with each other $(P$ $=0.06$ ) , and plasmin activity was particularly high in milk of cows of third or greater parity that had a 4 -wk dry period (7.4 units/mL, Figure 1A). Cows with a 4 -wk dry period had a $28 \%$ reduction in plasmin activity between 10 wk prepartum and 6 wk postpartum. Similar reductions in plasmin activity between late and early lactation have been reported in previous work, taking into consideration that all cows have a higher parity number after calving (Bastian et al., 1991). Plas-

Table 2. Milk yield and composition of cows after a dry period of 4 wk $(\mathrm{n}=25)$ or 8 wk $(\mathrm{n}=18)$ at 6 and 12 wk postpartum (mean \pm SEM)

\begin{tabular}{|c|c|c|c|c|c|c|c|c|c|}
\hline \multirow[b]{2}{*}{ Item } & \multicolumn{2}{|c|}{ Dry period length } & \multicolumn{2}{|c|}{ Week } & \multirow[b]{2}{*}{ SEM } & \multicolumn{4}{|c|}{$P$-value ${ }^{1}$} \\
\hline & 4 wk & $8 \mathrm{wk}$ & 6 & 12 & & Dry period & Breed & Parity & Week \\
\hline Fat $(\%)$ & 3.83 & 3.65 & 3.65 & 3.87 & 0.18 & 0.11 & $<0.01$ & 0.61 & 0.09 \\
\hline Protein (\%) & 3.39 & 3.30 & 3.33 & 3.39 & 0.05 & 0.24 & 0.54 & 0.70 & 0.04 \\
\hline $\mathrm{SCC}^{2}\left(\times 10^{3}\right.$ cells $\left./ \mathrm{mL}\right)$ & 280 & 356 & 268 & 333 & 155 & 0.31 & 0.01 & 0.20 & 0.92 \\
\hline Plasmin activity (units/mL) & 5.0 & 3.1 & 4.5 & 3.9 & 0.5 & $<0.01$ & 0.63 & 0.02 & 0.49 \\
\hline$\alpha_{\mathrm{S} 2}-\mathrm{CN}$ (\% of total protein) & 8.6 & 8.3 & 8.8 & 8.1 & 0.3 & 0.24 & 0.19 & 0.27 & $<0.01$ \\
\hline$\beta-\mathrm{CN}$ ( $\%$ of total protein) & 33.8 & 33.4 & 33.5 & 33.8 & 0.6 & 0.83 & 0.46 & 0.93 & 0.12 \\
\hline$\kappa-\mathrm{CN}$ (\% of total protein) & 10.3 & 10.9 & 10.5 & 10.6 & 0.4 & 0.53 & 0.20 & 0.31 & 0.90 \\
\hline$\alpha$-LA ( $\%$ of total protein) & 3.6 & 3.6 & 3.7 & 3.5 & 0.1 & 0.92 & 0.04 & 0.77 & $<0.01$ \\
\hline$\beta$-LG ( $\%$ of total protein) & 10.1 & 9.4 & 9.6 & 10.0 & 0.3 & 0.07 & 0.76 & 0.74 & 0.29 \\
\hline
\end{tabular}

${ }^{1}$ Also included in the model are the interactions dry period $\times$ breed, dry period $\times$ parity, dry period $\times$ week, breed $\times$ parity, breed $\times$ week, and parity $\times$ week.

${ }^{2}$ Statistical analysis based on log-values (SCC). 
min activity at 6 wk postpartum did not correlate with milk yield $10 \mathrm{wk}$ prepartum, and thus the postpartum difference in plasmin activity does not seem to be a result of the prepartum difference in milk yield between cows with a 4- or 8-wk dry period. In contrast to plasmin activity, plasminogen activity was higher in milk of second parity cows (66.3 units $/ \mathrm{mL}$ ) than of cows with greater parity ( 54.3 units $/ \mathrm{mL} ; P=0.03$ ). Plasminogen activity was not affected by dry period length, or by an interaction between dry period length and parity (Figure 1B). Plasminogen is transported transcellularly (Silanikove, 2016), and converted into plasmin by the influence of plasmin activators and plasminogen activator inhibitors. The current work shows an increase in plasmin activity in postpartum milk as a result of dry period reduction, though no change in plasminogen activity was found. If transcellular transport would be the main cause of increased plasmin activity in milk of cows with a 4-wk dry period, a proportional increase in plasminogen activity would be expected.

Plasmin activity in milk can reflect several processes in the mammary epithelium, such as mammary involution and epithelial cell proliferation (Politis, 1996). Plasmin was suggested to enhance epithelial cell proliferation by matrix degradation between cells during cell division (Saskela and Rifkin, 1988). The epithelium of the bovine mammary gland undergoes significant proliferation both prepartum (Capuco et al., 1997) as well as postpartum (Capuco et al., 2001). Mammary epithelial cell proliferation was found to occur at a lower rate for multiparous cows than for primiparous cows (Miller et al., 2006). A dry period was suggested to be important for regeneration of the mammary epithelium to prepare for a successive lactation, which was based on a higher cell regeneration rate of nonlactating mammary tissue compared with lactating tissue (Capuco et al., 1997). A 4 -wk dry period in combination with a low proliferation rate may therefore result in limited epithelial cell proliferation prepartum. A consequence may be increased proliferation postpartum compared with cows that had an 8-wk dry period. Ongoing cell proliferation in early lactation may be reflected by higher plasmin activity in milk due to the involvement of plasmin in mammary epithelial cell proliferation. The group of cows with high plasmin activity in milk consisted of both SH and SR, and consequently, the breed did not influence plasmin activity in the current study, although one could speculate that a dual-purpose breed (SR) may have a different mammary epithelial cell proliferation rate than a milk breed (SH). If there would be a breed effect on plasmin activity, this effect was less strong than the effect of parity, and therefore it did not appear in the current results. The role of plasmin activity in tissue remodeling is generally believed to be mediated
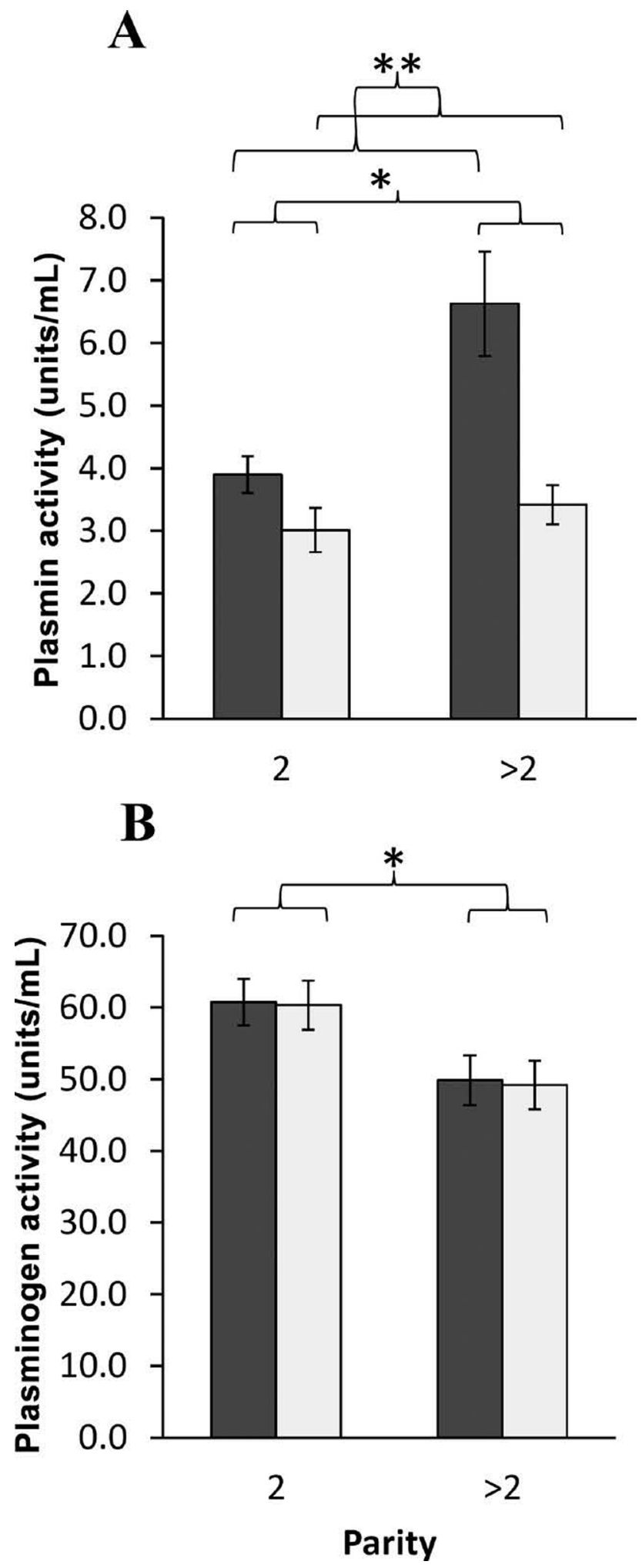

Figure 1. Plasmin activity (A) and plasminogen activity (B) in milk samples (6 and 12 wk postpartum) of cows with a 4-wk dry period (gray box) and of second parity $(\mathrm{n}=15)$ or parity greater than second $(\mathrm{n}=11)$, or an 8-wk dry period (white box) and of second parity $(\mathrm{n}=13)$ or parity greater than second $(\mathrm{n}=6)$. ${ }^{*} P<0.05$; ${ }^{* *} P<$ 0.01. Error bars indicate the SE. 
by urokinase-type plasminogen activators originating from somatic cells (Politis, 1996). Plasmin activity in postpartum milk of cows with a 4-wk dry period correlated exponentially with $\mathrm{SCC}\left(\mathrm{R}^{2}=0.30, P<0.001\right)$. This indicates that SCC is mediating plasmin activity in postpartum milk of cows with a 4-wk dry period, likely due to tissue remodeling. No relation was found between plasmin activity and SCC in postpartum milk of cows with an 8-wk dry period. It can be concluded that high-parity cows with a high milk yield prepartum that had a short dry period, had high plasmin activity in milk postpartum, which seems to reflect increased mammary epithelial cell proliferation.

In contrast to plasmin activity, none of the casein fractions was affected by dry period length, although the $\alpha_{\mathrm{S}_{1}} \mathrm{CN}$ fraction tended to be lower in milk of cows with a 4-wk dry period (29.5\%) than in milk of cows with an 8-wk dry period (30.1\%; Table 2). Plasmin activity correlated negatively with the $\beta$-CN fraction $\left(\mathrm{R}^{2}=0.21, P<0.001\right)$ and the $\alpha_{\mathrm{S} 1}-\mathrm{CN}$ fraction $\left(\mathrm{R}^{2}\right.$ $=0.20, P<0.001)$ when all postpartum milk samples were included. Plasmin activity correlated positively with the $\alpha_{S_{2}}$ CN fraction in postpartum milk samples $\left(\mathrm{R}^{2}=0.17, P<0.001\right)$. However, all these correlations were strongly determined by samples $(\mathrm{n}=2)$ with high plasmin activity $(>10$ units $/ \mathrm{mL})$. Like $\alpha_{\mathrm{S} 1} \mathrm{CN}$ and $\beta-\mathrm{CN}, \alpha_{\mathrm{S}^{-}} \mathrm{CN}$ can be degraded by plasmin (Kelly and McSweeney, 2003; Rauh et al., 2014) and therefore the positive correlation was not expected. This correlation may be caused by the use of casein fractions, which represent individual casein concentrations relative to the total protein concentration in the capillary zone electrophoresis profile. Hence, reduction of one fraction may indirectly result in the increase of another fraction. Previous work by us suggested increased proteolytic activity in early lactation when no dry period was applied, based on a low $\beta-\mathrm{CN}$ fraction. In the same study, no effect was found for cows with a short (30 d) dry period compared with a 60-d dry period (de Vries et al., 2015). The current work indicates that shortening the dry period to 4 wk can affect plasmin activity in milk, although the effect on casein composition is limited.

Increased plasmin activity may result in increased protein breakdown into peptides during ripening of (semi-) hard types of cheese. Peptide formation resulting from a 1.5- to 3-fold increase in plasmin activity, a similar increase as in the current work (Table 2), may increase cheese flavor development (Farkye and Landkammer, 1992), but may also result in undesired bitterness (Bastian et al., 1997). The current work indicates that dry period reduction may induce a comparable 1.5-fold increase in plasmin activity in early lactation, but despite this increase it is still lower than in late lactation. No overall plasmin-mediated effect of dry period length on casein composition was found, and thus this is not expected to influence cheese making properties. Because plasmin is a relatively heat-resistant enzyme, it can still be active in milk protein ingredients (Gazi et al., 2014) and UHT milk (Ismail and Nielsen, 2010). In UHT milk, plasmin has been shown to increase age gelation (Kohlmann et al., 1988; Rauh et al., 2014). Quantitative data about the influence of endogenous plasmin activity on storage stability of UHT milk are difficult to compare due to variations between studies in analytical and processing conditions. Pretreatment conditions of milk before UHT processing have a major influence on the effect of proteolysis on product properties (Rauh et al., 2014), and may therefore need to be considered. Future work is needed to evaluate UHT milk stability of early lactation milk from cows with a 4 -wk dry period. It is recommended to compare cows of different parities and include cows with a $0-d$ dry period to obtain a complete overview of the effect of dry period induced changes in plasmin activity on processing characteristics of milk.

In conclusion, applying a 4-wk dry period to multiparous cows resulted in high plasmin activity in postpartum milk, compared with an 8-wk dry period. This result indicated that the epithelium of these cows regenerated to a lesser extent than that of other cows. Increased plasmin activity, but unaffected plasminogen activity, indicated that applying a short dry period resulted in increased activation of plasminogen. Shortening the dry period to $4 \mathrm{wk}$ did not affect casein composition in milk. Milk with high plasmin activity was found to contain reduced $\alpha_{\mathrm{S1}^{-}} \mathrm{CN}$ and $\beta$-CN fractions. However, the effect of shortening the dry period on casein composition is not expected to give rise to concern for the cheese making industry.

\section{ACKNOWLEDGMENTS}

The authors thank the Swedish Farmer's Foundation for Agricultural Research (Stockholm, Sweden), Project H1130087, and SLUfood (Uppsala, Sweden) for their financial support. Thanks to Toon van Hooijdonk (Dairy Science and Technology, Wageningen UR, the Netherlands) for constructive advice in project discussions.

\section{REFERENCES}

Bastian, E. D., R. J. Brown, and C. A. Ernstrom. 1991. Plasmin activity and milk coagulation. J. Dairy Sci. 74:3677-3685.

Bastian, E. D., C. G. Lo, and K. M. M. David. 1997. Plasminogen activation in cheese milk: Influence on Swiss cheese ripening. J. Dairy Sci. 80:245-251.

Butler, W. R. 2003. Energy balance relationships with follicular development, ovulation and fertility in postpartum dairy cows. Livest. Prod. Sci. 83:211-218. 
Capuco, A. V., R. M. Akers, and J. J. Smith. 1997. Mammary growth in Holstein cows during the dry period: Quantification of nucleic acids and histology. J. Dairy Sci. 80:477-487.

Capuco, A. V., D. L. Wood, R. Baldwin, K. McLeod, and M. J. Paape. 2001. Mammary cell number, proliferation, and apoptosis during a bovine lactation: Relation to milk production and effect of bST. J. Dairy Sci. 84:2177-2187.

de Vries, R., A. van Knegsel, M. Johansson, H. Lindmark-Månsson, T. van Hooijdonk, K. Holtenius, and K. Hettinga. 2015. Effect of shortening or omitting the dry period of Holstein-Friesian cows on casein composition of milk. J. Dairy Sci. 98:8678-8687.

Dupont, D., B. Remond, and J. C. Collin. 1998. ELISA determination of plasmin and plasminogen in milk of individual cows managed without the dry period. Milchwiss. Milk Sci. Int. 53:66-69.

Farkye, N. Y., and C. F. Landkammer. 1992. Milk plasmin activity influence on cheddar cheese quality during ripening. J. Food Sci. 57:622-625.

Gazi, I., I. C. Vilalva, and T. Huppertz. 2014. Plasmin activity and proteolysis in milk protein ingredients. Int. Dairy J. 38:208-212.

Gumen, A., R. R. Rastani, R. R. Grummer, and M. C. Wiltbank 2005. Reduced dry periods and varying prepartum diets alter postpartum ovulation and reproductive measures. J. Dairy Sci. 88:2401-2411

Ismail, B., and S. S. Nielsen. 2010. Invited review: Plasmin protease in milk: Current knowledge and relevance to dairy industry. J. Dairy Sci. 93:4999-5009.

Kelly, A. L., and P. L. H. McSweeney. 2003. Indigenous proteases in milk. Pages 495-522 in Advanced Dairy Chemistry. Volume 1, Proteins. 3rd ed. P. F. Fox and P. L. H. McSweeney, ed. Kluwer Academic Publishers, Dordrecht, the Netherlands.

Kohlmann, K. L., S. S. Nielsen, and M. R. Ladisch. 1988. Effect of serine proteolytic-enzymes (trypsin and plasmin), trypsin inhibitor, and plasminogen-activator addition to ultrahigh temperature processed milk. J. Dairy Sci. 71:1728-1739.

Korycka-Dahl, M., B. R. Dumas, N. Chene, and J. Martal. 1983. Plasmin activity in milk. J. Dairy Sci. 66:704-711.

Kuhn, M. T., J. L. Hutchison, and H. D. Norman. 2005. Minimum days dry to maximize milk yield in subsequent lactation. Anim. Res. 54:351-367.

Mara, O., C. Roupie, A. Duffy, and A. L. Kelly. 1998. The curdforming properties of milk as affected by the action of plasmin. Int. Dairy J. 8:807-812.

Miller, N., L. Delbecchi, D. Petitclerc, G. F. Wagner, B. G. Talbot, and P. Lacasse. 2006. Effect of stage of lactation and parity on mammary gland cell renewal. J. Dairy Sci. 89:4669-4677.

Nicholas, G. D., M. J. Auldist, P. C. Molan, K. Stelwagen, and C. G. Prosser. 2002. Effects of stage of lactation and time of year on plasmin-derived proteolytic activity in bovine milk in New Zealand. J. Dairy Res. 69:533-540.

Politis, I. 1996. Plasminogen activator system: Implications for mammary cell growth and involution. J. Dairy Sci. 79:1097-1107.

Politis, I., K. Hang, and R. N. Giroux. 1989a. Environmental factors affecting plasmin activity in milk. J. Dairy Sci. 72:1713-1718.

Politis, I., E. Lachance, E. Block, and J. D. Turner. 1989b. Plasmin and plasminogen in bovine milk-A relationship with involution. J. Dairy Sci. 72:900-906.

Prado, B. M., B. Ismail, O. Ramos, and K. D. Hayes. 2007. Thermal stability of plasminogen activators and plasminogen activation in heated milk. Int. Dairy J. 17:1028-1033.

Rastani, R. R., R. R. Grummer, S. J. Bertics, A. Gumen, M. C. Wiltbank, D. G. Mashek, and M. C. Schwab. 2005. Reducing dry period length to simplify feeding transition cows: Milk production energy balance, and metabolic profiles. J. Dairy Sci. 88:1004-1014.

Rauh, V. M., A. Sundgren, M. Bakman, R. Ipsen, M. Paulsson, L. B Larsen, and M. Hammershoj. 2014. Plasmin activity as a possible cause for age gelation in UHT milk produced by direct steam infusion. Int. Dairy J. 38:199-207.

Saskela, O., and D. B. Rifkin. 1988. Cell-associated plasminogen activation: Regulation and physiological significance. Annu. Rev. Cell Biol. 4:93-120.

Schaar, J., and H. Funke. 1986. Effect of subclinical mastitis on milk plasminogen and plasmin compared with that on sodium, antitrypsin and $N$-acetyl-beta-D-glucosaminidase. J. Dairy Res. $53: 515-528$

Silanikove, N. 2016. Transcellular route as the most probable explanation for the presence of plasminogen in mammal's milk. J. Theor. Biol. 395:221-226.

Srinivasan, M., and J. A. Lucey. 2002. Effects of added plasmin on the formation and rheological properties of rennet-induced skim milk gels. J. Dairy Sci. 85:1070-1078.

van Knegsel, A. T. M., G. J. Remmelink, S. Jorjong, V. Fievez, and B. Kemp. 2014. Effect of dry period length and dietary energy source on energy balance, milk yield, and milk composition of dairy cows. J. Dairy Sci. 97:1499-1512.

van Knegsel, A. T. M., S. G. A. van der Drift, J. Cermakova, and B. Kemp. 2013. Effects of shortening the dry period of dairy cows on milk production, energy balance, health, and fertility: A systematic review. Vet. J. 198:707-713.

Watters, R. D., J. N. Guenther, A. E. Brickner, R. R. Rastani, P. M Crump, P. W. Clark, and R. R. Grummer. 2008. Effects of dry period length on milk production and health of dairy cattle. J. Dairy Sci. 91:2595-2603. 